\title{
ИНСТИТУТ ОСВОБОЖДЕНИЯ ОТ УГОЛОВНОЙ ОТВЕТСТВЕННОСТИ В РОССИЙСКОЙ ФЕДЕРАЦИИ И РЕСПУБЛИКЕ ТАДЖИКИСТАН: СРАВНИТЕЛЬНЫЕ АСПЕКТЫ
}

\section{FUNCTIONS OF THE INSTITUTE OF EXEMPTION FROM CRIMINAL LIABILITY IN THE RUSSIAN FEDERATION AND THE REPUBLIC OF TAJIKISTAN}

R. Azizov

Summary: The criminal legislation of many modern States provides for the institution of exemption from criminal liability. The article deals with the peculiarities of the institution of exemption from criminal liability in the Russian Federation and the Republic of Tajikistan. The author analyzes in detail the legal norms of criminal codes regulating the grounds of exemption from criminal liability. Based on this analysis, the author identifies certain similarities in legal regulation, as well as significant differences that correspond to the social, economic, legal and other characteristics of a particular state.

Keywords: exemption from criminal liability, grounds for exemption from criminal liability, reconciliation with the victim, compensation for damage, active repentance, a judicial fine, the expiration of the Statute of limitations, special types of exemption from criminal liability.
$\mathrm{B}$ рамках данной статьи наибольший интерес представляет правовая регламентация института освобождения от уголовной ответственности в Российской Федерации и Республике Таджикистан. Обращаясь к прошлому, стоит отметить, что до 1991 года Республика Таджикистан входила в состав Союза Советских Социалистических республик [2, С. 120]. Таким образом, до распада СССР правовая регламентация института освобождения от уголовной ответственности была полностью идентична. Однако, сейчас в каждом из рассматриваемых государств действуют свои уголовные кодексы, анализируя которые можно выделить как схожие черты в правом регулировании, так и существенные различия.

Для начала стоит отметить, что ни УК РФ, ни УК РТ не предлагают законодательной регламентации понятия «освобождение от уголовной ответственности», что порождает в науке уголовного права множество различных мнений по данному вопросу. Так, под освобождением от уголовной ответственности понимается отказ компетентных государственных органов от применения мер уголовно-правового характера в отношении лиц, совершивших деяние, в котором присутствуют все признаки состава преступления [3, С. 217]. Таким образом, в
Азизов Рустамбек Абдукодирович Адъюнкт, ФГКОУ ВПО «Московский университет Министерства внутренних дел Российской Федерации имени В.Я. Кикотя» rruussttiikk@list.ru

Аннотация: Уголовное законодательство многих современных государств предусматривает в своих нормах институт освобождения от уголовной ответственности. В статье рассматриваются особенности института освобождения от уголовной ответственности в Российской Федерации и Республике Таджикистан. Автор подробно анализирует правовые нормы уголовных кодексов, регламентирующих основания освобождения от уголовной ответственности. На основе данного анализа автор выделяет определенные схожие черты В правовом регулировании, а также существенные отличия, которые соответствуют социальным, экономическим, правовым и другим особенностям конкретного государства.

Ключевые слова: освобождение от уголовной ответственности, основания и виды освобождения от уголовной ответственности, примирение с потерпевшим, возмещение ущерба, деятельное раскаяние, судебный штраф, истечение сроков давности, специальные виды освобождения от уголовной ответственности.

случае отсутствия в деянии лица признаков конкретного состава преступления, предусмотренного уголовным законодательством, институт освобождения от уголовной ответственности не работает.

На основании вышеизложенного, можно предложить основные признаки освобождения от уголовной ответственности:

1. Освободить лица от уголовной ответственности можно только до вынесения приговора по конкретному уголовному делу;

2. При освобождении от уголовной ответственности к подозреваемому (обвиняемому, подсудимому) не применяются меры уголовно-правового воздействия, в том числе наказание;

3. Освобождение от уголовной ответственности применяется в случае нецелесообразности применения мер уголовно правового воздействия.

Таким образом, освобождение от уголовной ответственности как юридический факт, в силу которого реализуется охранительное уголовное правоотношение и аннулируются взаимные права и обязанности субъектов такого правоотношения. 
Как в Уголовном кодексе РФ, так и в Уголовном кодексе РТ основания освобождения от уголовной ответственности предусмотрены 11 главами. В целом данные главы схожи по содержанию [1; 4, С. 73]. В данном факте проявляется основная схожесть правового регулирования рассматриваемого института.

Что касается видов освобождения от уголовной ответственности, то тут существуют определенные различия. Так, в Уголовном кодексе РТ предусмотрены следующие четыре вида освобождения от уголовной ответственности: деятельное раскаяние лица, совершившего преступление, примирение с потерпевшим, изменение обстановки, истечение срока давности [4, C. 74]. В свою очередь Уголовный кодекс РФ предусматривает пять видов освобождения от уголовной ответственности, среди которых выделяют: деятельное раскаяние лица, совершившего преступление, примирение с потерпевшим, возмещение ущерба, назначение судебного штрафа и истечение сроков давности [1].

Таким образом, в кодексах анализируемых стран есть общие виды освобождения от уголовной ответственности, такие как: деятельное раскаяние лица, совершившего преступление, примирение с потерпевшим, истечение сроков давности. Отсутствуют в таджикском законодательстве такие виды освобождения от уголовной ответственности, как: возмещение ущерба и назначение судебного штрафа. Что касается изменения обстановки как вида освобождения от уголовной ответственности, то стоит отметить, что данный вид российский законодатель отменил в 2003 году, ранее данный вид был предусмотрен ст. 77 УК РФ.

Статья 72 УК РТ почти полностью дублирует статью 75 УК РФ. Обе статьи посвящены такому виду освобождения от уголовной ответственности, как деятельное раскаяние. В первых частях указанных статей рассматриваются основные условия освобождения от уголовной ответственности в связи с деятельным раскаянием. Среди них законодатели выделяют: преступление совершено впервые, преступление небольшой или средней тяжести, явка с повинной, активное способствование раскрытию и расследованию преступления, возмещен ущерб или вред заглажен иным образом [1; 4, С. 76]. Отличительной чертой УК РФ является то, что в нем указано, что вследствие деятельного раскаяния лицо совершившее преступление перестало быть общественно опасным.

Вторые части анализируемых статей являются полностью идентичными и делают акцент на преступлениях со всеми признаками, указанными в части первой, но относящимися к иным категориям. В данном случае законодатель обеих стран отсылают правоприменителя к статьям Особенной части Кодексов.
Следующим видом освобождения от уголовной ответственности является примирение с потерпевшим. Данное основание предусмотрено статьей 73 УК РТ и статьей 76 УК РФ. Данные статьи являются абсолютно идентичными и предполагают, что лицо, впервые совершившее преступление небольшой или средней тяжести, может быть освобождено от уголовной ответственности, если оно примирилось с потерпевшим и загладило причиненный потерпевшему вред $[1 ; 4$, C. 75$]$.

Еще одним видом, который предусмотрен законодательством обеих анализируемых стран, является истечение сроков давности. Анализируя статью 75 УК РТ и статью 78 УК РФ также можно сделать вывод об их идентичности. Части первые данных статей регламентируют размеры сроков давности по различным категориям преступлений. В российской Федерации и Республике Таджикистан они одинаковы: два года после совершения преступления небольшой тяжести, шесть лет после совершения преступления средней тяжести, десять лет после совершения тяжкого преступления, пятнадцать лет после совершения особо тяжкого преступления. Далее указаны правила исчисления сроков давности $[1 ; 4$, С. 76$]$.

Статья 74 УК РТ предусматривает такой вид освобождения от уголовной ответственности, как изменение обстановки. Стоит заметить, что данное основание существовало и в российском законодательстве, однако на данный момент Российский законодатель от него отказался. Согласно данному виду, если лицо совершило преступление небольшой или средней тяжести впервые и если в ходе предварительного следствия установлено, что совершившее противоправное деяние лицо или совершенное им противоправное деяние перестало быть общественно опасным, то лицо подлежит освобождению от уголовной ответственности [4, С. 77].

В свою очередь статья 76.1 УК РФ предусматривает такой вид освобождения от уголовной ответственности, как возмещение ущерба. Данный вид имеет место при совершении преступлений в сфере экономической деятельности. Для освобождения от уголовной ответственности необходимы следующие условия: совершение преступления впервые; совершение преступления предусмотренного статьями 198-199.1, 199.3, 199.4 УК РФ либо преступления, указанного в перечне ч. 2 ст. 76.1 УК РФ; возмещение ущерба, перечисление в федеральный бюджет денежного возмещения или дохода, полученного в результате совершения преступления, в объеме, предусмотренном ч. 2 ст. 76.1 УК РФ, либо денежной суммы, эквивалентной размеру убытков, которых удалось избежать в результате совершения преступления. Ущерб складывается из суммы недоимки по налогам и сборам, соответствующей пени, а также суммы штрафа в размере, определяемом согласно законодательству [1]. 
Статья 76.2 УК РФ регламентирует правила освобождения от уголовной ответственности в связи с назначением судебного штрафа. Лицо, впервые совершившее преступление небольшой или средней тяжести, может быть освобождено судом от уголовной ответственности с назначением судебного штрафа в случае, если оно возместило ущерб или иным образом загладило причиненный преступлением вред. Особенностью этого вида освобождения от уголовной ответственности является то, что рассматриваемый вид является условным, поскольку в случае неуплаты судебного штрафа в установленный судом срок освобождение отменяется и лицо привлекается к уголовной ответственности по соответствующей статье Особенной части УК РФ [1].

Рассматривая вопрос специальных видов освобождения от уголовной ответственности, стоит сказать, что законодатель обеих стран идентично подходят к данному вопросу. Так, законодатели обеих стран создают примечания к статьям Особенных частей Кодексов, в которых предусматривают дополнительные условия освобождения от уголовной ответственности. Так, например, согласно примечанию к статье 130 УК РТ и примечанию К статье 126 УК РФ лицо, добровольно освободившее похищенного, освобождается от уголовной ответственности. Подобная конструкция примечаний содержится в других статьях Особенных частей анализируемых Уголовных кодексов.

Статья 82 УК РТ и статья 84 УК РФ регламентируют применение акта амнистия как вид освобождения от уголовной ответственности. Актом об амнистии лица, совершившие преступления, могут быть освобождены от уголовной ответственности [1; 4, С. 78]. Схожесть в правовом регулировании проявляется в том, что амнистия в обоих государствах объявляется в отношении индиви- дуально не определенного круга лиц. Отличие состоит в том, что в России амнистия объявляется Государственной Думой Федерального Собрания Российской Федерации, а в Таджикистане необходимо принимать Закон Республики Таджикистан о применении амнистии. Также, стоит отметить, что законодатель Республики Таджикистан дополнительно указывает на то, что акт амнистии распространяется на уголовно наказуемые деяния, совершенные до его принятия, российский законодатель об том умалчивает.

Анализируя вопросы освобождения от уголовной ответственности несовершеннолетних, стоит отметить, что в УК РФ данному вопрос посвящены три статьи (ст.ст. 90, 91, 92 УК РФ), а УК РТ всего одна статья (ст. 90 УК РТ) [1; 4, С. 78]. Однако, несмотря на это оба законодателя идентично указывают на то, что если несовершеннолетний впервые совершает преступление небольшой или средней тяжести, то может быть освобожден от уголовной ответственности с применением к нему мер воспитательного характера. Сами меры воспитательного характера, как в России, так и в Таджикистане одинаковы, среди них законодатель выделяют: предупреждение, передача под надзор родителей, ограничение досуга, возмещение причиненного преступлением вреда.

Проанализировав все вышеизложенное, стоит отметить, что в Уголовном кодексе РФ и Уголовном кодексе РТ в отношении правового регулирования института освобождения от уголовной ответственности имеются как схожие моменты, так и существенные отличия. Схожесть правового регулирования обусловлена тем, что оба государства ранее входили в состав Союза ССР, и после его распада законодатели кардинально не изменяли уголовные кодексы. Различия обусловлены свойственными политическими, экономическими и социальными аспектами развития рассматриваемых стран.

\section{ЛИТЕРАТУРА}

1. Уголовный кодекс Российской Федерации: Федеральный закон от 13 июня 1996 г. N 63-Ф3 // Собрание законодательства РФ. 1996. № 25. Ст. 2954.

2. Колесников Р.В. Ретроспективный анализ института освобождения от уголовной ответственности и от наказания // Общественная безопасность, законность и правопорядок в III тысячелетии. 2017. № 3-1. С. 118-123.

3. Панов А.А. Проблемы законодательного регулирования освобождения от уголовной ответственности как формы уголовно-правового воздействия // Социальная политика и социология. 2016. № 10 (64). С. 215-220.

4. Тайфуров 3. Освобождение от уголовной ответственности по Уголовному кодексу Республики Таджикистан // Вестник Таджикистанского Национального университета. 2014. № 3-5. С. 73-78.

(с Азизов Рустамбек Абдукодирович (rruussttiikk@list.ru). 